\section{The heroic art of storytelling}

\section{Glenn C. Conroy}

Narratives of Human Evolution. By Misia Landau. Yale University Press: 1991. Pp. 202. \$25, £14.

SOME people get no respect. Thomas Macaulay once said that the more he read Socrates, the less he wondered why they poisoned him, and Thomas Jefferson was no less charitable to Plato when he remarked that the only thing remaining after one tuok away his "sophisms, futilities and incomprehensibilities" was century biologists Thomas H. Huxley, Charles Darwin, Ernst Haeckel, Arthur Keith and Grafton Elliot Smith in order to identify nine functions that she believes characterize all narratives of human evolution: (1) the initial condition in which the evolutionary hero is found (in all narratives of human evolution this setting is usually in a relatively carefree arboreal environment); (2) the hero is introduced as being somehow slightly 'different' from other nonhuman primates lurking in the vicinity; (3) the hero has to leave home (the change of situation in being dislodged from his arboreal home); (4) the hero departs to begin a new journey or adventure (for example, life as a terrestrial biped); (5) the hero is tested (by predators, climate, other ultimately civilization. Obviously, for Darwin, principles of natural selection were the operative mechanism (the hero's helper or donor) during this journey. For Keith, on the other hand, orthograde posture evolved while ancestral humans were still in trees and this, rather than terrestriality per se, was the initial point of departure for human evolution. As an anatomist fascinated with the newly discovered role of hormones in growth and development, Keith subscribed to the orthogenetic view that "the machinery of evolution will be found inside the factory of the womb, rather than in the mechanism of natural selection". (Keith was an influential champion of the authenticity of the Piltdown Man and Galley Hill, and a
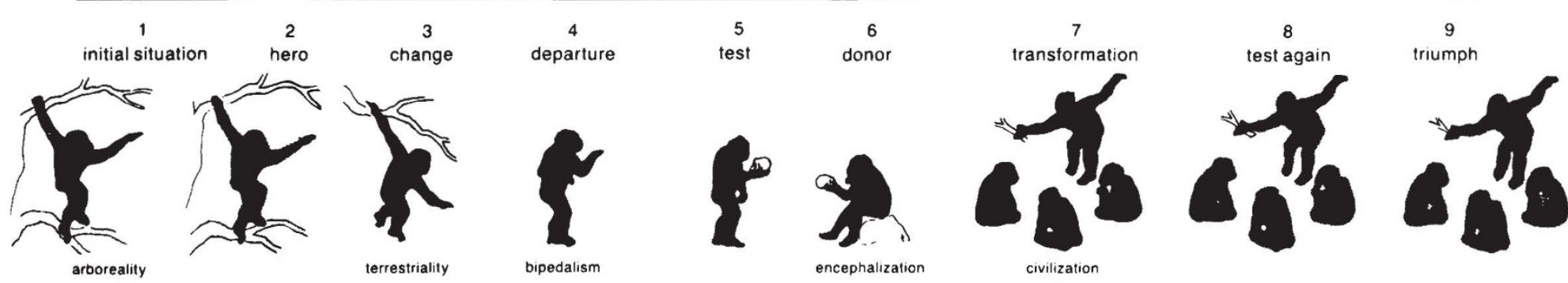

"his foggy mind". Fossil hunters, too, have been held in similar contempt by their detractors, often molecular biologists and cladists, who sometimes regard the literary byproduct of their sweat, blood and tears (to coin a phrase) as little more than the art of storytelling.

In Narratives of Human Evolution, the palaeoanthropologist-cum-literary-critic Misia Landau, rescues the art of anthropological storytelling by analysing just how complex these stories really are and what their underlying structures reveal about the basic evolutionary and social principles of their authors (what she refers to as "this altar housing a deep diversity of faiths").

Landau considers any account of a sequence of events that manifests "a deeper kind of belonging" (such as the story of human evolution) as a form of narrative that can be studied by techniques of literary criticism. Using methods originally developed by Vladimir Propp in Morphology of the Folktale (University of Texas Press, 1928), an analysis of Russian folktales, Landau first breaks down narratives of human evolution into their component, or functional, parts. A critical step in such an analysis is to dissect the tale "according to the functions of its dramatis personae" (that is, the evolutionary heroes). These functions then become the basic components of the tale.

Using a case-study approach, Landau liberally quotes from the works of the influential nineteenth- and twentieth- closely related species and so on); (6) a donor or helper appears that enables the hero successfully to fend off the challenges found on the journey, thus becoming the main explanatory force for evolutionary change in the story (such as natural selection, orthogenesis, neolamarckism); (7) gifts are bestowed on the hero (for instance, increasing brain size, intelligence, language, tools, morals) and he is duly transformed; (8) the hero is tested once again; and (9) the hero finally triumphs, that is, civilization (usually European) is attained.

The most enlightening aspect of such an analysis is the recognition that these nine actions, or functions, of the dramatis personae can assume very different meanings depending on where they occur in the narrative. In other words, although stories of human evolution may take similar narrative forms and all share the same time functions, their underlying meanings may differ substantially depending on which function is regarded as the prime mover in the story and which evolutionary mechanism (the donor or helper) operates as the hidden agent of evolutionary change.

For example, the prime mover in Darwin's narrative of human evolution was the shift to terrestriality, that is, when ancestral hominids left the relative safety of the trees to face life in the tall African grass. Thus, terrestriality set off a cascade of evolutionary events that led almost inexorably to the evolution of bipedality, tool-use, encephalization and defamer of the Taung Child - one winces at how dreadful so many of his judgements were about the fossil record.) Both Darwin and Keith at least had a podiatristic view of human evolution, believing that human evolution commenced feet-first. Elliot Smith, as befitted a neuroanatomist, saw human evolution from a head-first perspective, that is, with increasing encephalization being the prime mover in human evolution, occuring long before ancestral humans hit the ground. Like Keith, he was also an orthogenist. But as Landau recognizes, Elliot Smith's donor lies buried in the hidden recesses of the brain (Elliot Smith's Tomb) whereas Keith's donor resides within the embryo (Keith's Womb).

Landau's approach to palaeoanthropology is informative and entertaining. Her analyses of the writings of Huxley, Darwin, Haeckel, Keith and Elliot Smith are incisive and provocative, and lay bare the biases that each brought to their narratives. This makes it all the more unfortunate that her treatment of more contemporary narratives of human evolution, such as those by Theodosius Dobzhansky, Raymond Dart, J. T. Robinson, Phillip V. Tobias and Donald Johanson, are not as fully developed as one would have hoped. This is a disappointment rather than a criticism. For example, Landau's seemingly hurried analysis of the debate of Johanson, Tim White and Bill Kimbel with Tobias over Australopithecus africanus and $A$. 
afarensis seems almost trivial in comparison to her more compelling and dramatic critical assessment of Darwin, Huxley and Haeckel's struggles with more herculean evolutionary themes. I would be fascinated to see Landau dissect contemporary icons of palaeoanthropology with the same surgical blades she uses on our idols of the past.

Science can be conveniently divided into three classes: the 'soft sciences' such as sociology and political science, the 'hard sciences' such as physics and chemistry and then the 'really difficult sciences' such as palaeoanthropology. Narratives of Human Evolution is a literate, thought-provoking explication of this really difficult science. I would add only one further thought to Landau's story. She notes that Huxley never did bridge that gap between the apes and humanity with a missing link. Maybe that is because the missing link is man.

Glenn C. Conroy is in the Department of Anatomy and Anthropology, Washington University Medical School, St Louis, Missouri 63110, USA

\section{Theories for everything}

\section{A. Hallam}

Extinction: Bad Genes or Bad Luck? By David M. Raup. Norton: 1991. Pp. 210. $\$ 19.95$.

The Miner's Canary: Unravelling the Mysteries of Extinction. By Niles Eldredge. Simon and Schuster: 1991. Pp. 246. \$20.

AlTHOUGH argument persists about the extent to which Darwin was a gradualist when it came to modes of speciation, with The Origin of Species being quoted like so much Holy Writ, there is no room for doubt about his views on the relative importance of biotic as opposed to physical causes in promoting extinction. "Species are produced and exterminated by slowly acting causes .... and the most important of all causes of organic change is one which is almost independent of altered . . . physical conditions, namely the mutual relation of organism to organism - the improvement of one organism entailing the improvement or the extermination of others". This 'struggle for existence' view has been accepted uncritically by generations of evolutionary biologists, and is well expressed in Van Valen's famous Red Queen hypothesis, named after Lewis Carroll's character who found that, in her sort of country, it took all the running one could do to stay in the same place.
Thus, in the darwinian view, the biologically 'superior' mammals would have progressively outcompeted the dinosaurs through the course of the Mesozoic era, until dinosaurs eventually became extinct. It is now clear that this did not happen - mammalian radiations had to await the disappearance of the dinosaurs together with many contemporary terrestrial and marine organisms, a disappearance caused by mass extinction resulting from drastic environmental deterioration at the end of the Cretaceous period. Any competition between the dinosaurs and mammals must therefore have been pre-emptive rather than displacive, the key requirement being to be the first to occupy the ecological niche. This pattern of change appears to be characteristic of the fossil record as a whole, with episodic mass extinctions clearing the decks, as it were, for the radiation of new organic groups. In Raup's words, extinction appears to have been more a matter of bad luck than bad genes, because normal darwinian finely tuned adaptations would often have been a poor defence against a rare environmental catastrophe.

These two books on extinction by leading US palaeontologists are aimed at a wide audience and demand little technical knowledge. Both books have considerable merits but are very different in their treatment of the subject, reflecting the different aptitudes and interests of their authors. Raup's great strength is his skill in handling data statistically and his ability to make incisive points on the basis of this quantitative approach. $\mathrm{He}$ presents a penetrating discussion of randomness, based on such diverse topics as the 'gambler's ruin' problem and the skewed distributions ubiquitous in nature, and uses this to argue cogently for rarity being the main factor promoting extinction. He makes a pertinent comparison of mass extinctions with more familiar natural phenomena such as earthquakes and floods, with the events of greatest intensity being the least frequent. His disturbingly named "kill curve" depicts the average number of species killed for a series of waiting times, and hence tells us the average likelihood of a given event in a given length of time; needless to say, mass extinctions fall high on the curve.

The title of Eldredge's book refers to the canaries used by miners as early warning systems for poisonous gases. The recent decline of migrating songbirds fits the same role on a global scale, and is clearly a measure of habitat destruction, which in his view has always been the main cause of extinction. Eldredge writes as lucidly as Raup, but his style is less dry and more eloquent, and his book is richer than Raup's in biological examples. He outlines the reasons for the diversity of the organic world, indicating that rates of speciation and extinction are higher in specialist forms: the higher diversity of the tropics is largely a consequence of finer nichepartitioning among more stenotopic organisms. Mass extinctions are in his view dramatic events that extended over millenia or longer, and are not normally the consequence of geologically instantaneous catastrophes.

In reviewing the possible physical causes of mass extinctions in the prehuman past, neither author is dogmatic and both freely admit to the continuing uncertainty and dispute within the scientific community. Because Raup believes that nature would have great difficulty eliminating species over large areas, he favours the crash of asteroids or comets into the Earth as the cause of not just mass extinction, but background extinction as well. This is, to my mind, a truly astonishing conclusion, being based on virtually no evidence apart from the pronounced iridium anomalies and shocked quartz at the Cretaceous/ Tertiary boundary, which is the only reason why the impact story is taken seriously at all. Eldredge takes what I believe to be the geologically more reasonable view, for which there is much evidence from the stratigraphic record. In this view, important environmental changes bound up with events confined to our planet are responsible for mass extinctions. He sees no need to invoke deus ex machina of extraterrestrial events except for the Cretaceous/ Tertiary boundary extinctions; even here, any impact was probably no more than a coup de grâce to elements of an already perturbed biosphere.

Although he does not discount sealevel change, Eldredge favours climatic deterioration as the most important extinction-inducing factor. I think that he overstates the case. Whereas falling temperature appears to have been implicated in the Cenozoic and late Ordovician extinctions, the evidence for other times ranges from poor or equivocal to nonexistent. Further, there is a strong correlation between marine extinction and global sea-level change: relatively sudden falls led to extensive regression of epicontinental seas, and, probably more importantly, sharp rises were associated with the spread of anoxic waters. Both could have caused devastating loss of habitat area. Despite the strong evidence for these phenomena, Raup does no more than mention them in passing, whereas Eldredge ignores them completely. In particular, these events get around the objection made by Raup that the pronounced regressions of the Quaternary period do not correlate with important extinction episodes, and hence the case 